\title{
Community forestry, Italian style: The Magnifica Comunità di Fiemme
}

\author{
by Peter N. Duinker ${ }^{1}$ and Reino E. Pulkki ${ }^{1}$
}

In June 1997, we visited the Magnifica Comunità di Fiemme (MCF), a community forest in the Alps of northern Italy. We have prepared this article to help broaden the perspectives of Forestry Chronicle readers on community forests and what they mean in various parts of the world. We first describe the area and its forests, and then give a brief history of the MCF. Then we review the forest-management strategies used in this Norway spruce forest, and summarize the logging and wood-processing activities of the enterprise. We continue with a comparison of this community forest with three community forests in Canada, concluding that generalization on what makes a community forest successful is dangerous - each situation is unique. Finally, given that the MCF recently won permission to use the eco-label of the Forest Stewardship Council (FSC), we discuss our perceptions of how the MCF operation does and does not meet the FSC's Principles and Criteria of Forest Stewardship. Despite several shortcomings, we believe that the MCF is in most respects a sound example of sustainable forest management.
Nous avons visité, en juin 1997, la Magnifica Comunita di Fiemme (MCF), une forêt communautaire située dans les Alpes, dans le nord de l'Italie. Nous avons rédigé cet article dans le but d'informer les lecteurs du Forestry Chronicle sur ce que sont les forêts communautaires et ce qu'elles signifient dans différentes parties du monde. Nous décrivons en premier lieu le territoire et ses forêts, puis nous donnons un bref historique de la MCF. Par la suite, nous révisons les stratégies d'aménagement forestier utilisées dans cette forêt d'épinette de Norvège, et nous décrivons sommairement les activités d'exploitation et de façonnage des bois au sein de l'entreprise. Nous poursuivons en comparant cette forêt communautaire avec trois forêts communautaires du Canada, pour enfin conclure qu'identifier les points communs de ce qui fait le succès des forêts communautaires est une chose dangereuse, compte tenu que chaque cas est particulier. Finalement, étant donné que la MCF a obtenu dernièrement la permission d'utiliser l'écoétiquette du Forest Stewardship Council (FSC), nous discutons de notre perception des opérations du MCF qui répondent et qui ne répondent aux critères et principes de gestion des forêts du FSC. Malgré quelques aspects incomplets, nous considérons que la $\mathrm{MCF}$ constitue de façon générale un bon exemple d'aménagement forestier durable.

\section{Introduction}

Community forestry continues to be discussed in Canadian policy dialogues through the 1990s. Some see the concept as a mechanism for local people to increase their involvement in forest decision-making. Others see it as a way to increase people's physical, economic and emotional connections with forests, perhaps even to secure employment. Yet others envisage community forestry as the only way to achieve sustainable forests and sustainable communities at the same time. Complementing this wide range of objectives is an equally wide variety of situations referred to as community forests - they exist in all sizes, ownerships, forest types, management structures, and silvicultural strategies, to name but a few important dimensions. And they exist around the world, differing markedly between developed and developing countries (Mallik and Rahman 1994).

In June 1997, we visited a community forest in northern Italy as part of a field trip organized by the Community Forestry Unit at the Forestry Department of the UN Food and Agriculture Organization (FAO) in Rome. We have prepared this article to help broaden the perspectives of Forestry Chronicle readers on community forests and what they mean in various parts of the world. Thus, the paper complements the series of articles that appeared in the December 1994 issue of The Forestry Chronicle (Volume 70, Number 6) on community forests in

\footnotetext{
${ }^{1}$ Faculty of Forestry, Lakehead University, Thunder Bay, Ontario, Canada P7B 5E1. e-mail: pduinker@lakeheadu.ca)
}

Canada (Duinker et al. 1994). Here we give a glimpse of what community forest means in the Alps of southern Europe. Then we compare and contrast the Magnifica Comunità di Fiemme (MCF) with the Canadian situation.

In addition, in May 1997, the MCF was the subject of a certification audit by SGS Ltd. of the UK. The objective was to seek a blessing to use the ecolabel of the Forest Stewardship Council (FSC) on its wood products. Having succeeded, the MCF was the first such certified forest in the Alps. At the end of the article, we convey our impressions of what this eco-certification of the MCF means to us from a Canadian perspective.

While in the MCF, we took photos and video footage. We have assembled a series of images, with text annotations,

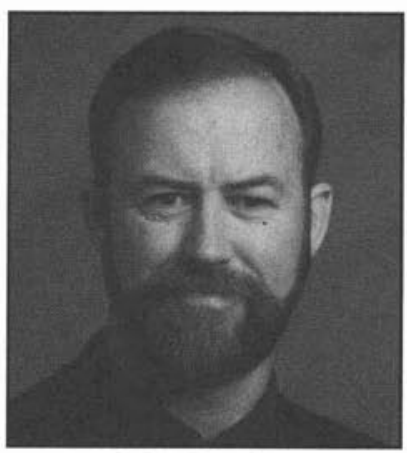

P.N. Duinker

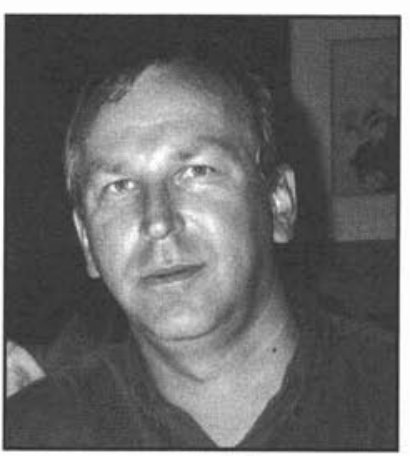

R.E. Pulkki to complement this paper. This additional documentation may be found on the web page of Reino Pulkki at the Faculty of Forestry, Lakehead University (http://www.lakeheadu.ca). 


\section{The Area and Its Forests}

The MCF's land holdings are in the southeastern Alps (Figure 1), east of the city of Trento and some two- hours drive north of Venice. The mountains are of dolomitic structure, and range in elevation in this area from the valley floor (e.g., Cavalese) at about $1,000 \mathrm{~m}$ asl up to the highest peaks at some $2,500 \mathrm{~m}$ asl. The tree line is at about $2,300 \mathrm{~m}$ asl. The climate tends toward that of Central Europe, with average annual rainfall of some $1,000-2,000 \mathrm{~mm}$. The mountain soils have few nutrient limitations for tree growth.

The MCF's eleven communities lie in the lower section of the Avisio River valley. The valley's inhabitants number about 20,000 (Morandini, 1996). The economy has been driven for centuries by agriculture and forestry, but has now become strongly dominated by tourism. Skiing is especially popular in the area.

The MCF forest is dominated by one species, Norway spruce (Picea abies [L.] Karst.). Other species include: larch (Larix decidua Mill.) and Scotch pine (Pinus sylvestris L.) on abandoned rangelands and steep slopes, or mixed with spruce; Swiss stone pine (Pinus cembra L.) at high elevations; and, rather rarely, silver fir (Abies alba Mill.) and beech (Fagus sylvati$c a$ L.). The domination by Norway spruce is partly a function of climate and topography, and partly a function of the longstanding propensity of local foresters to favour spruce because of its high-quality and much-sought-after timber.

The total land area owned by the MCF is about 19,600 ha (not all contiguous), with about 11,400 ha in forest, about 7,000 ha in alpine meadows, pasture and rangeland, and some 1,200 ha that is non-productive (Morandini 1996). The forest is divided into protection forests of 2,700 ha (these are on high elevations and erosion-sensitive slopes), and production forests of 8,700 ha. The total growing stock is estimated at 3.7 million $\mathrm{m}^{3}$, which amounts to an average of approximately $330 \mathrm{~m}^{3} / \mathrm{ha}$. In the production forest, growing stock averages about $390 \mathrm{~m}^{3} / \mathrm{ha}$, and can peak at over $1,000 \mathrm{~m}^{3} / \mathrm{ha}$. The total annual increment is about $60,000 \mathrm{~m}^{3} / \mathrm{yr}$ (or an average of about $5 \mathrm{~m}^{3} / \mathrm{ha} / \mathrm{yr}$ ). Tree heights are usually over $30 \mathrm{~m}$, with many stands reaching 40 and even $50 \mathrm{~m}$. In the typical Norway spruce stands, boles are cylindrical and branch-free for about one quarter of their height.

\section{History and Organization of the MCF}

The MCF is a partly private, partly public institution, known under Italian civil law as a unique sui generis institution. It has no affiliation today with the local governments. Such a communal or collective institution was common in central Europe during the Middle Ages, and there are signs that they existed well before the Roman conquest (Merlo 1995). However, with time most of them were claimed by feudal lords or by nation-states which kept the land in public ownership or assigned it to individuals as private property.

Through the first millennium, the MCF managed to retain its character and independence partly because of its geographic isolation. ${ }^{2}$ In July 1111 , the Bishop-Prince of Trento officially recognized the MCF, and in return got agreement that

\footnotetext{
2"Particularly in the most remote alpine valleys, niches of indigenous populations remained isolated and free to organize their social and economic life, unaffected by the political and economic changes experienced in urban society" (Merlo 1995).
}

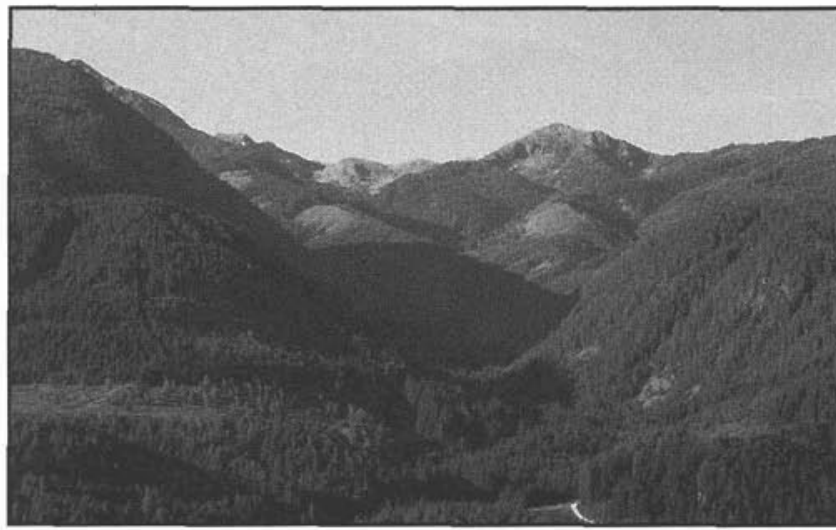

Fig. 1. The forest landscape of the Magnifica Comunità di Fiemme.

his office could administer justice in the area (Boninsegna and Felicetti undated). Through the second millennium the MCF repeatedly had to re-confirm its status with the BishopPrinces of Trento, until finally receiving a formal recognition from the Supreme Court of Italy in 1951.

Besides the forest, the MCF also owns a small museum/palace, a new administrative building and a sawmill. The land is held as common property by the MCF members, and what makes the MCF unique is that the land is unalienable. One can become a member of the MCF only by residing in one of the eleven communities of the Val di Fiemme. If you are born in the valley, you are a member, but you must remain a resident (Morandini 1996). If you move into the valley, you need to reside there for 20 years before becoming a member ${ }^{3}$. If you move out, you lose membership. ${ }^{4}$ There are today almost 19,000 vicini (individual members).

The organization is structured much like a private corporation. Each member community has a common assembly of members. Three representatives are voted into the MCF common assembly by each of the community assemblies. The executive body is comprised of the single representative of each community who received the highest number of votes. The executive body elects a president, and the MCF common assembly appoints typical corporate boards such as controllers and auditors boards.

The MCF historically had the goal of supporting the socioeconomic development of its communities as well as the interests of the vicini. For the communities this meant that $\mathrm{MCF}$ profits would frequently be spent on community infrastructure such as roads, hospitals, schools, and libraries (Morandini

\footnotetext{
${ }^{3}$ Twenty years may seem a long time, but the MCF constitution was recently changed to raise the eligibility requirement from five years to 20 . The longtime residents are enjoying the economic boom brought by tourism, but felt that too many non-residents who were buying condominiums in the valley for both hiking and skiing vacations were claiming membership too early (i.e., after only five years of ownership).

${ }^{4}$ Predazzo, one of the eleven communities in the MCF, has its own community forest, but its membership structure is rather different. Only men descendent from the original 21 founding families may be members. A young man becomes a member when his father dies. The family of a member who does not bear a son loses the right to membership, and is thereupon paid a small compensation. Today there are almost 800 members. Residence is not required for sustaining one's membership, but one must remain active in the organization. Membership is lost after five years of inactivity.
} 
1996), as well as helping specific needy families. These functions have now been taken over largely by provincial and local governments. For the members, there was the possibility of employment or contract work, although this is now a smaller part of the overall economy of the area. Finally, all members are eligible to receive an equal portion of the profits. Long ago, these were substantial ${ }^{5}$, but today they are nominal. However, membership is still a powerful status symbol, and is coveted by many.

\section{Forest Management}

The forest is run by two professional foresters (a director and vice-director) and some ten technicians. The MCF manages the production forest mainly for timber. ${ }^{6}$ The maximum allowable cut has been calculated to be $47,000 \mathrm{~m}^{3} / \mathrm{yr}$, and current harvest levels amount to about $35,000 \mathrm{~m}^{3} / \mathrm{yr}$ of industrial roundwood.

Timber management focuses mainly on the Norway spruce, partly because it dominates the forest and partly because it does so well, given its quality, in the marketplace. The production forest is divided into ten spatial units. Each unit has its own management plan, and the units are on a cycle so that the foresters (or their consultants) are preparing one plan per year, for about one tenth of their forest area. ${ }^{7}$ Each plan goes through a long process of official approvals, including one from the provincial government. Approved plans have the force of law. Public participation in planning is essentially non-existent there is only one short opportunity to inspect and comment on the final plan late in the process.

The silvicultural systems match those used throughout the Alps. Most of the Norway spruce stands are even-aged. One or two commercial thinnings are done. Final fellings are small clearcuts (patchcuts and stripcuts), usually on the order of about half to one hectare (Figure 2). Stripcuts are usually no wider than one half the canopy height (which ranges from 30 to $40 \mathrm{~m}$ ). In thinnings and selection cuts, all the trees to be harvested are marked by the foresters or technicians. Aesthetics guidelines regarding shape and placement of the cuts seem unimportant - many are plainly visible from the streets in the valley towns (see Figure 1). Dead stems, as well as blowdowns (which may be several to tens of hectares in extent), are harvested immediately, partly to salvage economic value and partly to prevent bark beetle infestation. The result is a forest without snags and coarse woody debris. ${ }^{8}$ Natural regeneration is

\footnotetext{
${ }^{5}$ We learned that, long ago, parents of young women in the Predazzo area were always asking whether their daughters' boyfriends were vicini with the Predazzo community forest enterprise. Upon marriage, vicino status assured the young couple of a steady small income from the community forest's profits! In the early years of the venture, the profits could amount to several months' salary; now they are no more than a tenth of one month's salary.

${ }^{6}$ Other lands are managed for grazing (especially for dairy farming to produce specialty cheeses), from which the MCF also fetches income (Morandini 1996). The MCF also rents land to a ski enterprise. Among the non-timber forest values important in this forest are fishing and mushroom-picking. Vicini have cost-free rights to fish in streams within their territory, while non-vicini must pay for a licence. Mushroom picking is popular, for both locals and tourists; however, it is strictly regulated under Italian law, and the MCF hires four "guards" to prevent over-harvesting. Non-vicini pay a fee to pick mushrooms.

${ }^{7}$ As part of the inventory routine, the MCF foresters are required to measure the diameter at breast height of fully half the trees in each spatial unit in advance of management planning. Under such circumstances, planning for only about $800 \mathrm{ha} / \mathrm{yr}$ seems a good idea!
}

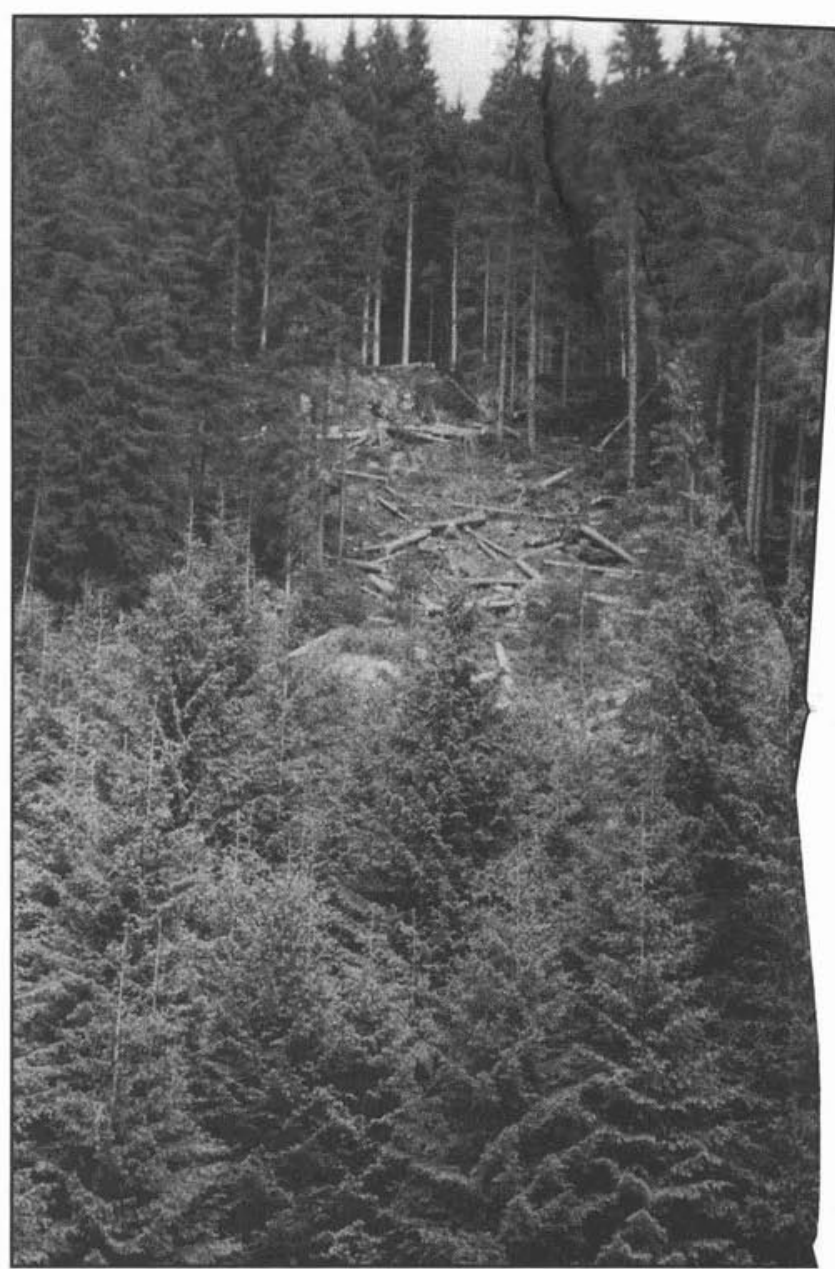

Fig. 2. A typical patch-cut in the MCF Norway spruce forest.

preferred and planned, but the MCF has a small tree nursery and plants Norway spruce where needed (e.g., in larger blowdown salvage cuts, and fill-planting in regular cuts) (Figure 3). Harvested trees are limbed and topped where felled, and the larger pieces close to roads are taken by vicini for firewood.

According to Morandini (1996), forest management took a significant turn in the $1980 \mathrm{~s}$. The forests were deemed excessively mature and overmature, with high volumes and depressed increments. A more aggressive harvest policy had to be implemented. The forests are to be kept essentially even-aged, but would be divided into a finer mosaic of stands. Spacing of young stands is now routinely practised, favouring the best trees to "... increase the stability of the stands and reduce wind and snow damage ..." (Morandini 1996).

\section{Wood Harvesting and Processing}

Logging operations are largely contracted out to small local firms, of which presently only one is operated by a non-vicini. Coupes with negative stumpage (e.g., salvage cuts) are generally logged by the MCF's own personnel (i.e., some 50 to 100 seasonal workers), who also carry out other

${ }^{8}$ These forests have been managed for many centuries in such a way that snags and coarse woody debris have been absent (M. Albani, Faculty of Forestry, University of British Columbia, personal communication, July 1997). 


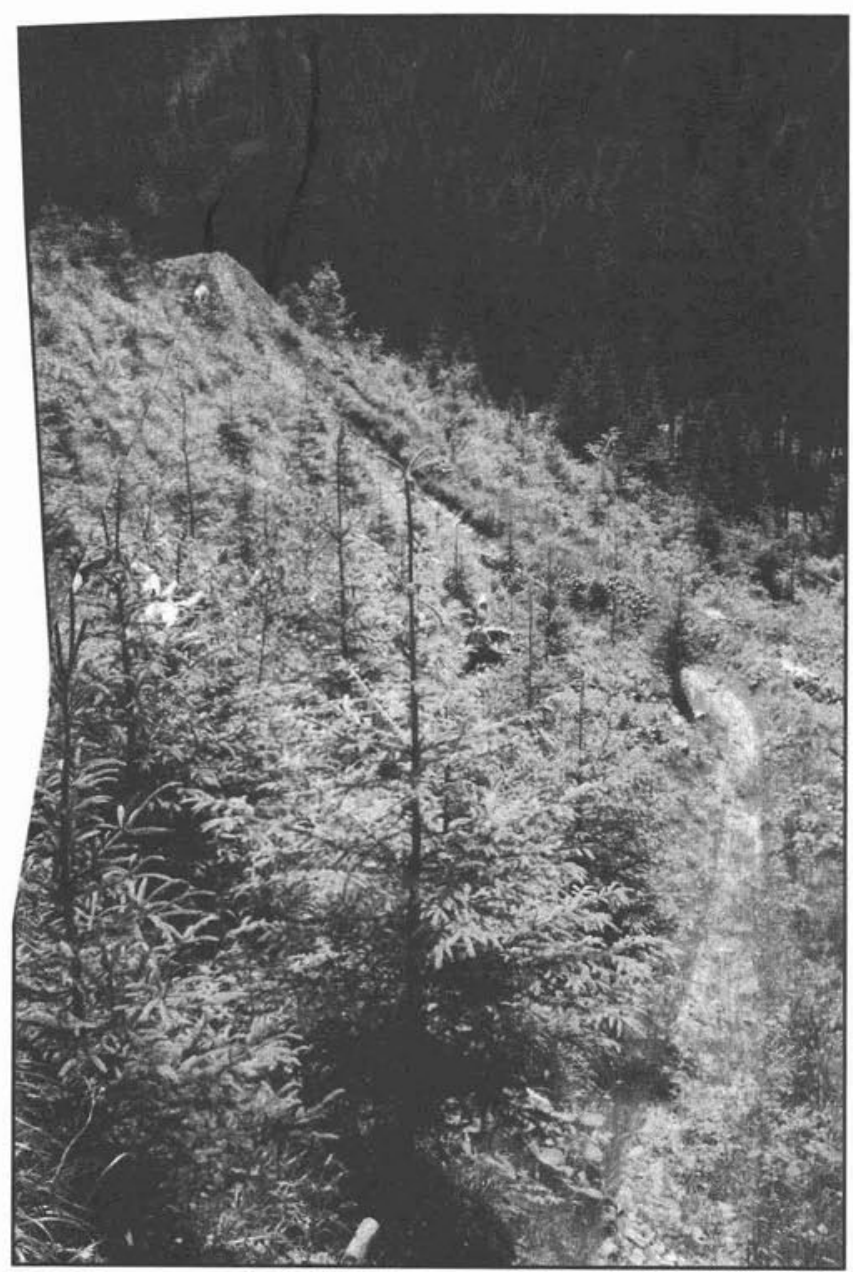

Fig. 3. A mixture of planted and natural Norway spruce regeneration in a patch cut in the MCF Norway spruce forest. The stone-lined trench leading from the right foreground toward a peak in the left background is actually a reconstructed chute which was used to transport logs to lower elevations for eventual hauling to the sawmill in the valleybottom.

forest operations. For cut areas with positive stumpage, local logging contractors are invited to bid for the logging contract. To be invited, the logging contractor must be on the MCF registry. Logging contractors must follow the silvicultural prescriptions closely, and cause minimal damage to the site and residual trees; otherwise they can be removed from the registry and/or charged a penalty on final payment.

Logging contractors are responsible for felling, limbing, bucking and extraction to roadside. Hauling to the mill is usually subcontracted. Logging generally occurs during the snow-free period of the year, mainly because a large proportion of the logging workforce works at the ski resorts during the winter. Cutting is by chain saw, with extraction occurring one to two weeks later with a small dual-drum skyline yarding system (e.g., Pollini et al. 1989). Spinelli (1995) outlined the characteristics of the most commonly used yarders in Italy. The carriage can be a manual slack-pulling carriage (Hartsough et al. 1992, Marchi 1993) or equipped with a powered winch (Spinelli 1995), so a lateral skidding distance of 15 to $30 \mathrm{~m}$ to the yarding corridor is possible in both clear and partial cut- ting situations. Depending on the yarder and terrain conditions, the maximum yarding distance generally ranges from 200 to $600 \mathrm{~m}$; however, intermediate supports are required for the longer distances (FAO 1981, Spinelli 1995). Logging operations are done carefully, with minimal soil disturbance and minimal damage to residual trees in partially cut areas and along clearcut boundaries. We estimated that less than $2 \%$ of residual trees in the thinning areas visited had lower stem or root collar wounds.

The average logging cost (1996) was $40,000 \mathrm{LIT} / \mathrm{m}^{3}$ (approximately $32 \mathrm{CAD} / \mathrm{m}^{3}$ ), while the cost of truck transport for the average $20-30 \mathrm{~km}$ distance was about $10,000 \mathrm{LIT} / \mathrm{m}^{3}$ $\left(8 \mathrm{CAD} / \mathrm{m}^{3}\right)$. The average stumpage price for standing timber was $120,000 \mathrm{LIT} / \mathrm{m}^{3}\left(96 \mathrm{CAD} / \mathrm{m}^{3}\right)$. All industrial roundwood is transported to the sawmill, where the small wood is sold as fence posts and the larger logs processed into lumber.

Within the last decade, the MCF sawmill in Ziano di Fiemme was restructured and modernized, and a finger-jointing line installed (Morandini 1996). By Central European, Nordic or North American standards, it is classed as a small sawmill, but it is the largest Italian mill processing domestic roundwood. The sawlog input is totally from the MCF forest, and amounts to about $35,000 \mathrm{~m}^{3} / \mathrm{yr}$. The sawnwood output is $21,000 \mathrm{~m}^{3}$ (lumber yield $60 \%$ ). Of the sawnwood, $9,000 \mathrm{~m}^{3}$ of the lower-grade knotty lumber is directed to the finger-jointing line. Here the knots are cut out, and value-added, high-quality finger-jointed material is produced for the joinery, door and window-frame industries. Although the final production of finger-jointed material is $5,850 \mathrm{~m}^{3}$ ( $65 \%$ yield on rough lumber input), it accounts for $50 \%$ of the sales receipts for the sawmill. There were two major objectives for the installation of the finger-jointing line: one was to employ the workers displaced by the modernization and automation of the sawmill, and the other was to obtain more value from the lower-grade lumber. The sawmill employs about 35 people year-round.

\section{Comparisons and Contrasts with Community Forests in Canada}

There is, of course, no standard form of community forest in Canada (Duinker et al. 1994), but we can take some oft-cited examples for comparison and contrast with the MCF. Let us examine several dimensions in which the MCF is like and unlike Canadian community forests, which here will include the North Cowichan Municipal Forest (NCMF) and Mission Municipal Forest (MMF) in BC (Allan and Frank 1994), and the Geraldton Community Forest (GCF) in Ontario (Harvey and Hillier 1994). We consider these three Canadian experiences as successes in community forestry.

\section{Relationship with Local Government}

The MCF is not associated in any formal way with local governments. There is a rule that a town mayor may not be a member of the MCF assembly. Both the NCMF and the MMF are arms of local government, whereas the GCF is not. Thus success in a community forest venture does not seem to hinge on formal links with local government.

\section{Membership Basis of Organization}

The MCF is a membership-based organization. Likewise, so is GCF, where every voting-age citizen living in the community-forest territory is a voting member of the corporation. 
However, neither the NCMF nor the MMF are membership organizations. Thus, a variety of organizational structures may work for successful community forests.

\section{Wood Processing}

The MCF would be of marginal economic viability if it did not have a state-of-the-art sawmill making specialty, high-valueadded products. In contrast, none of the Canadian community forests has a wood-processing facility. The NCMF and MMF both sell logs in a quasi-competitive market, and the GCF has no timber rights at all except what it has arranged in an agreement with the company holding the timber concession on the provincially-owned community forest land. There is much discussion, however, about how Canadian community forests might boost their economic viability by using wood locally for a variety of purposes (e.g., using low-quality wood in co-generation plants). Thus, there is a wide range of situations with respect to timber rights, production and processing among successful community forests.

\section{Public Participation}

The MCF has virtually no public participation in day-to-day forest management decision-making. However, the vicini, through their various assemblies, take a strong role in strategic decision-making about the organization itself, its financial affairs (investments and profit allocations), and land-use issues. Non-vicini have no input at either level. The concept of community forest in Canada definitely means increasing participation opportunities (e.g., through open houses and public advisory committees) for all people, community and otherwise, in forest decision-making (Ontario Forest Policy Panel 1993).

\section{Ecological Sustainability}

The MCF is practising traditional alpine silviculture for wood production, with little regard, in our view, for naturalness of forest ecosystems and non-timber values such as biodiversity. ${ }^{9}$ Community forests in Canada must, if they are on public land, take naturalness and biodiversity into account in contemporary silviculture programs (e.g., Frankin et al. 1997), just like industrial forest enterprises must (e.g., the Crown Forest Sustainability Act of Ontario (1994), and the Forest Practices Code Act of BC (1994)).

\section{Conclusions}

The specific conditions for success in any community forest seem to be unique. They are clearly dependent on local social, economic and ecological conditions (Matakala and Duinker 1993). This means, unfortunately, that few global generalizations can be drawn about what conditions are necessary for a successful community forest. We return to the success of MCF later.

\section{FSC Certification}

There is great interest around the world today in the concept of certification of forest management systems and woodproducts. Some schemes, such as that of the Canadian Standards Association (CSA 1996), purport to demonstrate whether a forest is sustainably managed, and issue a certificate verifying so, and others, such as that of the FSC, to demonstrate, through an eco-label, that wood-based products are derived from materials harvested from well-managed forests (Elliott and Hackman 1996).

In 1996, the MCF began the process of seeking cerification under the FSC's program. A preliminary site visit was onducted in 1996, and a certification audit in May 1997by SGS Ltd. of Oxford, UK, under the Qualifor program. The auct was successful, and the MCF was authorized as of September 1997 to affix the FSC eco-label to its wood products (L Pettenella, pers. comm., 1998).

Based upon our observations while visiting the MCF and discussing matters with its forest manager, and upon the FSC Principles and Criteria for Forest Stewardship (FSC 1996), we have come to the following preliminary impressions. ${ }^{10}$ As a model of ecologically gentle timber production directed by local people for their own ecological, social and economic benefits, the MCF is running a superb operation. Much of what is going on in and at the MCF is fully in compliance with the FSC Principles and Criteria. For example, Principle \#2 (tenure and use rights and responsibilities) is well in hand, and Principle \#3 (indigenous people's rights) hardly applies. The chain of custody provision (criterion 8.3) is a cinch to fulfill, because the MCF sawmill processes only wood coming from the MCF forest. However, we believe the MCF falls short of FSC requirements in at least the following ways:

Criterion 4.4 - We saw no evidence of an explicit evaluation of social impact, as we understand the concept in an North American context (e.g., Burdge 1994). We also were told that public participation does not functionally exist. While the vici$n i$ have a voice, non-vicini essentially do not. The MCF clearly undertakes projects and expends funds for social purposes (e.g., creating special recreational areas, running courses on mushroom ecology, hiring displaced and handicapped workers), but does not implement social impact assessment.

Criterion 6.1 - We saw no evidence of an explicit evaluation of environmental impacts, at least in the sense of environmental impact assessment as a formal process (e.g., Beanlands and Duinker 1984, Gilpin 1995, Morris and Therivel 1995, Sadler 1996). Again, in some respects great care is taken to avoid environmental impacts, as in the construction of new roads, which is evidence of rigorous environmental planning. However, this does not constitute environmental impact assessment.

Criterion 6.3 - The biodiversity of the MCF is far from natural biodiversity (i.e., the biodiversity that might have existed there before humans had a significant effect on the forest

\footnotetext{
${ }^{10} \mathrm{We}$ realize that our basis for evaluation is neither complete nor systematic. Clearly, to be absolutely thorough in our assessment, we should have spent more time examining MCF practices and documents, as well as the SGS audit protocol.
}

\footnotetext{
${ }^{9}$ This is not to say, however, that traditional alpine silviculture focuses only on timber. Broadleaved trees are often left unharvested, avifaunal nesting areas are preserved, mushroom collecting, flower picking, fishing and hunting are regulated, and certain biotopes are totally protected. The MCF territory includes more than 2,700 ha of protected land.
} 


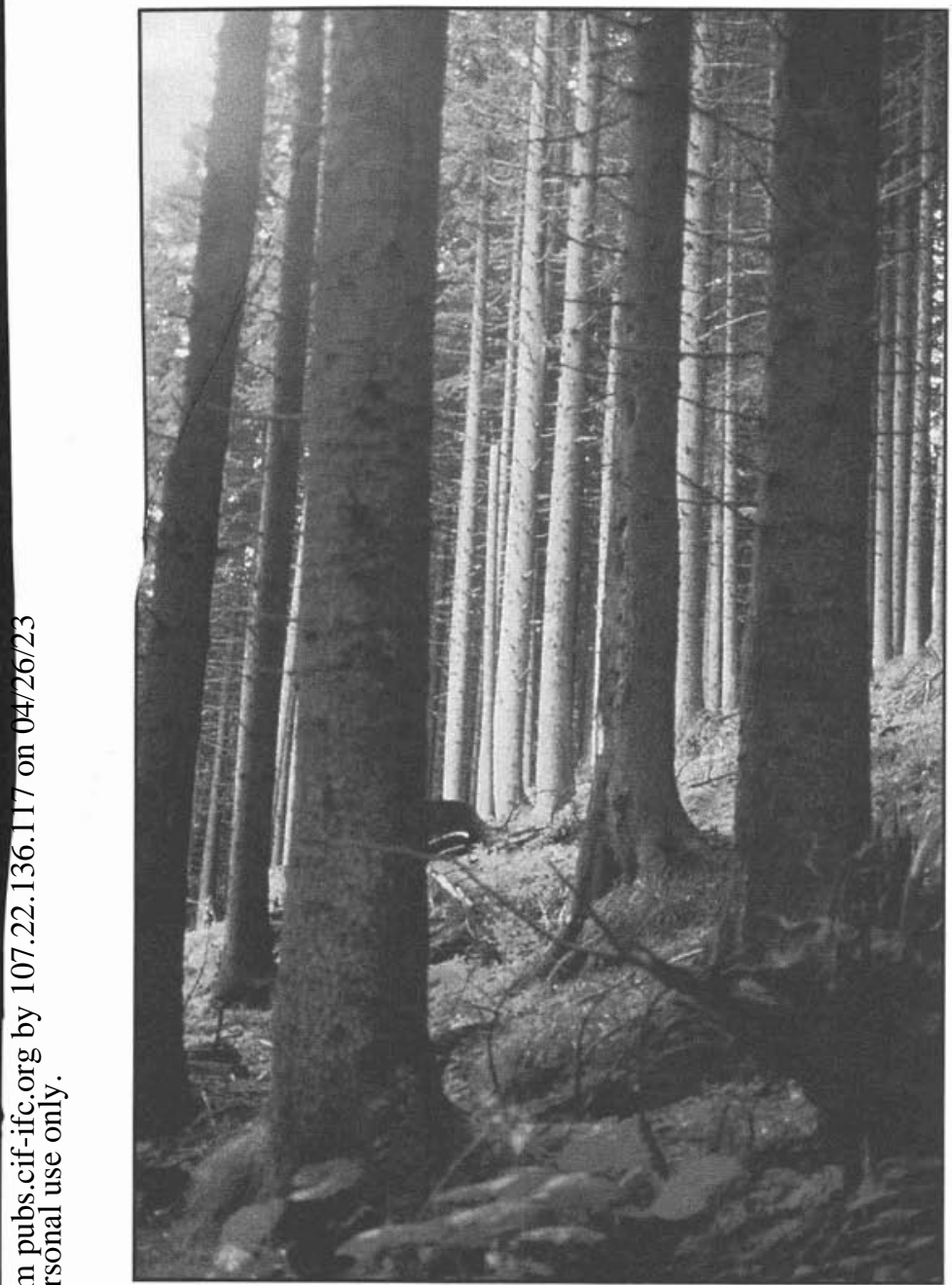

Fig. 4. The park-like nature of the Norway spruce forest of the MCF. Coarse woody debris is almost universally removed from the forest as soon as it is created. Note the high density of large, wellformed trees, and the "wildlife" tree near the centre of the picture (it is riddled with woodpecker holes).

ecosystems and their components). Surely under natural conditions, these forests would contain huge amounts of snags and coarse woody debris, and would have periodically sustained large blowdowns and, less frequently, stand-replacing wildfires. We saw evidence that this criterion was, indeed, not fulfilled. Even single dead or windthrown trees were salvaged immediately. The production forest had a "park-like" appearance - tall trees, easy to walk beneath with visibility at ground level impeded only by huge tree trunks (Figure 4). We acknowledge that the MCF does include a few thousand hectares (about one quarter of the total estate) of non-production forest (and thus natural forest) at high elevations and on sensitive sites (Figure 5).

Criterion 8.2- We were unaware of any systematic research and data collection activities, in the sense of effects monitoring (Duinker 1989, 1997a), related to environmental and social impacts.

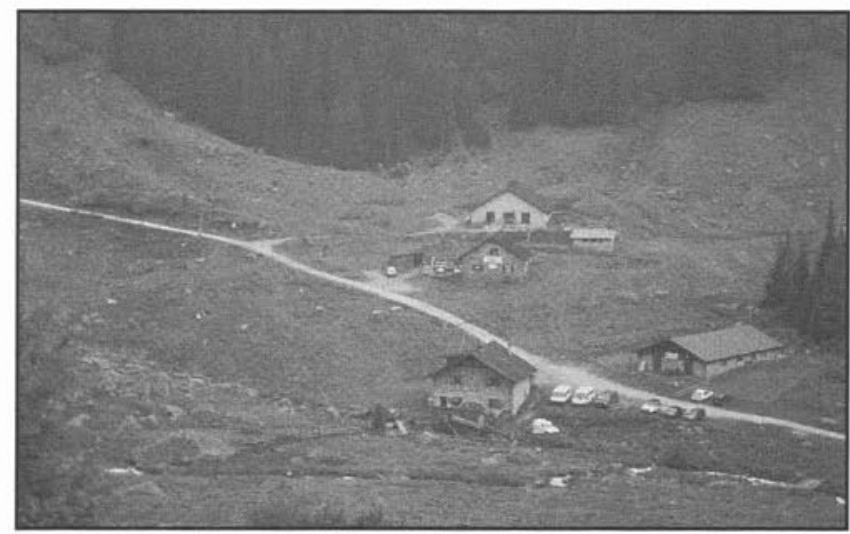

Fig. 5. At high elevations, the MCF territory is dominated by a mixture of alpine meadows and natural forest. Several of the meadows are leased to farmers who pasture cattle there and make specialty cheeses locally. Very fine meals can be had in such alpine restaurants as the one in the foreground. Local wines and grappa complement the hearty cuisine.

Criterion 9.1 - We are aware that MCF foresters supplement natural regeneration with planting of indigenous stock, but this is definitely not a case where "plantings shall not replace or significantly alter the natural ecosystem." In a word, these are not natural ecosystems. ${ }^{11}$ They are forests highly re-arranged by humans for many centuries, mainly for the express purpose of timber production.

To summarize, on economic grounds the MCF enterprise looks sustainable. On social grounds, we sensed that the local people were well satisfied with how the MCF was being managed and the benefits they received. The limited public participation did not seem to bother anyone. However, ecologically speaking, the MCF is not an example of natural forest management. Perhaps the emerging concept of semi-natural forest applies well here, but there are some strong differences between the ecological characteristics of the MCF production forest today, and the same forest if it were unaffected by humans.

\section{Conclusions}

Is the $\mathrm{MCF}$, in our view, a success story? In socio-economic terms, and in terms of low-impact logging, indeed it is. How can the MCF be, for such a long time, such a success? Here are some key factors:

(a) Social factors. The people of Val di Fiemme have a strong pride in their centuries-long venture. The MCF never lost its momentum over the ages, something Merlo (1995) considered vital:

“... experience has shown that it is extremely difficult to reconstruct communal forestry in areas where it has dis-

\footnotetext{
"We find it interesting that the FSC principles and criteria were once called "Principles and Criteria for Natural Forest Management," but, with the recent approval by the FSC of Principle \#10 on plantations, they are now called "Principles and Criteria for Forest Stewardship," and they apply to all forests. Are the MCF forests natural or plantations? We judge them to be closer to plantations than to natural forests. International organizations concerned with forests (e.g., FAO) now favour a third category, that of semi-natural forests, in which the MCF forests would certainly fall.
} 


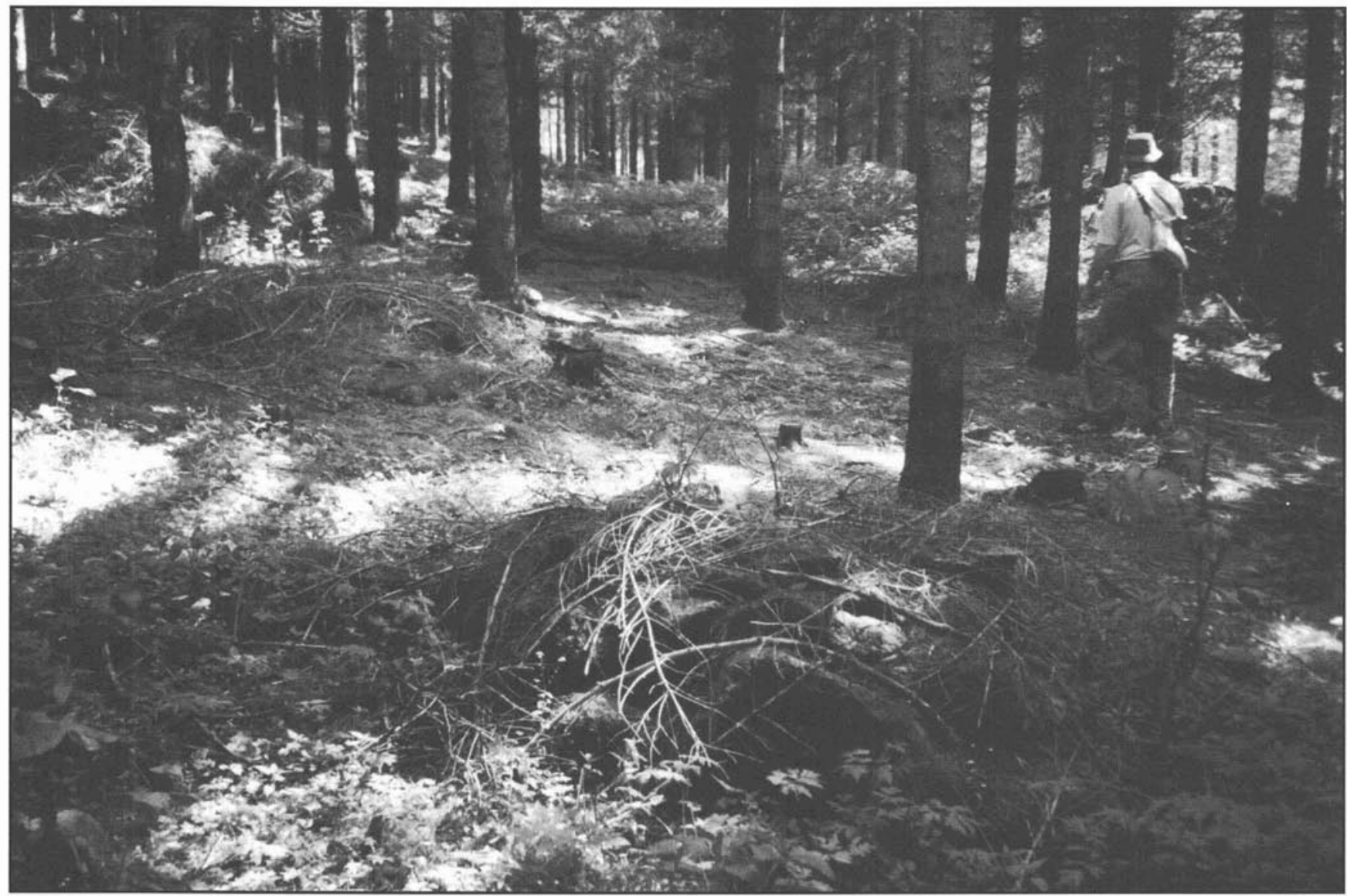

Fig. 6. The working forest at MCF is much altered by human activity. In the foreground is a stone pile covered with brush.

appeared ... It must be recognized that these institutional policies have generally been successful only where people still retain a memory of and pride in ancient traditions."

(b) Economic factors. The MCF has a strong emphasis on quality timber grown and processed locally. The sawmill is key to economic viability - not any sawmill, but one that can process value-added products for specialty markets. Additional incomes in the communities, especially from tourism, and to the MCF, particularly from rental of land for a ski resort, help in a major way.

(c) Ecological factors. The MCF has the advantage of owning some of the best timber-producing land in Europe. Soils are nutrient-rich, the climate is favourable, and wood growth rates and wood quality are high.

Given a North American perspective on forest ecology - one of conserving natural biodiversity and ecosystem functions (e.g., Hunter 1990, Kohm and Franklin 1997) — the MCF is, in our view, not a success. But perhaps this perspective needs modification. Perhaps if we consider humans as a vital part of forest ecosystems, as most paradigms of ecosystem management and sustainable forest management would have us do (Behan 1997), then the concept of what is natural (usually meaning with little influence from humans) has little meaning and therefore little value (Duinker 1997b). Perhaps what counts is what people, in a thoughtful and considerate way using informed consensus-oriented decision-making, want to happen in and for their forests. When that occurs, then perhaps we have a "sustainable" situation (Duinker 1997c). This seems to be the case for the Magnifica Comunità di Fiemme!

\section{Acknowledgements}

We gratefully acknowledge: our colleagues in the Forest Products Division at FAO - Hermann Schmincke, Olman Serrano, and Gary Bull - for supporting us in this work; the Community Forestry Unit at FAO — Kadi Warner and Daniel Shallon - for organizing the trip; and Dr. Davide Pettenella (Dipartimento Territorio e Sistemi Agroforestali, Universita Degli Studi di Padova) and Stefano Cattoi (Director of Forestry, MCF) for hosting and guiding the visit and providing information. A great deal of data were provided in an unpublished manuscript by M. Albani ("The Magnifica Comunità di Fiemme," due to be published as part of a FORWARD Study Area Report by the European Forest Institute in Finland). We also thank Davide Pettenella for reviewing an early draft of the paper.

\section{References}

Allan, K. and D. Frank. 1994. Community forests in British Columbia: models that work. For. Chron. 70(6): 721-724.

Beanlands, G.E. and P.N. Duinker. 1984. An ecological framework for environmental impact assessment. Journal of Environmental Management 18: 267-277.

Behan, R.W. 1997. Scarcity, simplicity, separatism, science and systems. pp. 411-417 In Creating a Forestry for the 21st Century: 
The Science of Ecosystem Management. K.A. Kohm and J.F. Franklin, eds. Island Press, Washington, DC, USA.

Boninsegna, A. and M. Felicetti. Undated. La Magnifica Comunità di Fiemme: Guide to Palace. Magnifica Comunità di Fiemme, Cavalese, Italy. 38 p.

Burdge, R. 1994. A Conceptual Approach to Social Impact Assessment. Social Ecology Press, Middleton, Wisconsin, USA. 256 p. CSA. 1996. A Sustainable Forest Management System: Guidance Document. CAN/CSA-Z808-96, Environmental Technology: A National Standard of Canada. Canadian Standards Association, Etobicoke, ON. 33 p.

Duinker, P.N. 1989. Ecological effects monitoring in environmental impact assessment: what can it accomplish? Environmental Management 13: 797-805.

Duinker, P.N. 1997a. Forest certification: New hope for monitoring environmental impacts of forest management. Paper presented at a workshop on "Environmental Assessment Follow-up," at University of Toronto, April 1997, and in press in the refereed workshop proceedings.

Duinker, P.N. 1997b. Managing Ontario's Forests as Natural Landscapes: Opportunities and Challenges. Manuscript under revision for publication in The Forestry Chronicle.

Duinker, P.N. 1997c. Criteria and indicators of sustainable forest management: Canadian experiences and directions. Paper in press in a volume of edited papers from the 1995 Summer Sustainability Workshop, International Institute for Applied Systems Analysis, Laxenburg, Austria.

Duinker, P.N., P.W. Matakala, F.Chege and L. Bouthillier. 1994. Community forests in Canada: An overview. For. Chron. 70(6): 711-720.

Elliott, C. and A. Hackman. 1996. Current Issues in Forest Certification in Canada. Discussion Paper, WWF Canada, Toronto, Ontario, Canada. 63 p.

FAO. 1981. Cable Logging Systems. Forestry Paper 24, Food and Agriculture Organization of the United Nations, Rome, Italy. 105 p. FSC. 1996. Principles and Criteria for Forest Stewardship. Forest Stewardship Council, Oaxaca, Mexico.

Franklin, J.F., D.R. Berg, D.A. Thornburgh and J.C. Tappeiner. 1997. Alternative silvicultural approaches to timber harvesting: variable retention harvest systems. pp. 111-139 In Creating a Forestry for the 21st Century: The Science of Ecosystem Management. K.A. Kohm and J.F. Franklin, eds. Island Press, Washington, DC, USA. Gilpin, A. 1995. Environmental Impact Assessment: Cutting Edge for the Twenty-first Century. Cambridge University Press, Cambridge, UK. 182 p.
Hartsough, B.R., B.J. Stokes and C. Kaiser. 1992. Short-rotation poplar: a harvesting trial. Forest Products Journal 42(10): 59-64. Harvey, S. and B. Hillier. 1994. Community forestry in Ontario. For. Chron. 70(6): 725-730.

Hunter, M.L. Jr. 1990. Wildlife, Forests, and Forestry: Principles of Managing Forests for Biological Diversity. Prentice-Hall, Englewood Cliffs, NJ, USA.

Kohm, K.A. and J.F. Franklin. (eds). 1997. Creating a Forestry for the 21st Century: The Science of Ecosystem Management. Island Press, Washington, DC, USA. 475 p.

Mallik, A.U. and H. Rahman. 1994. Community forestry in developed and developing countries: A comparative study. For. Chron. 70(6): 731-735.

Marchi, E. 1993. Messa a punto di una gru a cavo di tipo economico per l'esbosco su brevi distanze: attrezzatura, sistemi di impiego e produttività (A low-cost cable crane for short distance skidding: equipment features, systems of use and outputs). Annali Accademia Italiana di Scienze Forestali 42: 227-258.

Matakala, P. and P.N. Duinker. 1993. Community Forestry as a Forest-Land Management Option in Ontario. pp. 26-58 In Forest Dependent Communities: Challenges and Opportunities. D. Bruce and M. Whitla, eds. Rural and Small Town Research and Studies Program, Mount Allison University, Sackville, NB.

Merlo, M. 1995. Common property forest management in northern Italy: a historical and socio-economic profile. Unasylva 46(1): 58-63.

Morandini, R. 1996. A modern forest-dependent community: the Magnifica Comunità di Fiemme in Italy. Unasylva 47(3): 47-52.

Morris, P. and R. Therivel. 1995. Methods of Environmental Impact Assessment. UBC Press, Vancouver, BC. 378 p.

Ontario Forest Policy Panel. 1993. Diversity: Forests, Peoples, Communities. Report of the Ontario Forest Policy Panel. Ministry of Natural Resources, Toronto, Ontario. 147 p.

Pollini, C., G. Leonelli, G. Gios and M. Olivari. 1989. Introduzioine di razionali tecnologie nelle utilizzazioni forestali: prove di esbosco con una gru a cavo a stazione motrice mobile (Introduction of appropriate logging methods: a work study with a mobile skyline crane). Istituto per la Tecnologia del Legno, Quaderni I.T.L. No. 18: 7-33. Sadler, B. 1996. Environmental Assessment in a Changing World: Evaluating Practice to Improve Performance. Final Report of the International Study of the Effectiveness of Environmental Assessment. Canadian Environmental Assessment Agency, Hull, QC. 248 p. Spinelli, R. 1995. Le gru a cavo per l'esbosco in terreni pendenti (Cable cranes for log extraction on sloping terrain). Macchine e Motori Agricoli 53(10): 17-21. 